\title{
ANALYSIS OF MASS-MEDIA AFFECTED TRANSFORMATIONS OF THE DANGER CONCEPT
}

\author{
Elena V. Lavrova, \\ Lidiya V. Matveeva \\ Lomonosov Moscow State University, \\ Moscow, Russia
}

The article deals with a study of both short-term and long-term influence of massmedia upon a concept of danger (CD). Subjective concepts of danger (CD) were revealed by means of the authors "Assessment of Dangerous Situations" Questionnaire and a new classification of such concepts was developed. Demonstrated are differences in CD of men and women, as well as specific traits of CD transformations induced by news programs. The authors give advice on how to compile TV news programs in view of psychological mechanisms of perception.

Keywords: concept of danger, mass-media, TV, news discourse, 'Assessment of Dangerous Situations' Questionnaire.

The origin of a sign as a special regulator of human activities brought about changes in these activities and in human mental life in general. A sign became an instrument for human mental activities and a means for controlling human self-conduct and behavior of others (Vygotsky, 1960).

Language is a developed system of signs via which a person can transmit information quickly enough both in oral and written forms. The speed of information transmission grew gradually. The invention of book-printing put the first step in this field, then periodicals (newspapers and magazines) appeared, and later the telegraph was invented. The other means of information transmission were developed in the XX century: cinema, television, and the Internet. Various mass-media begin to play a very important role in the contemporary world. Due to a global character of this process, this new historic stage is conventionally called the Information Revolution. 
As a result of this information revolution with its technological innovations, the information transmitted has lost its direct connection with a source, i.e. a narrator. M. McLuhan describes how emerging technologies were changing social relations and a style of human thinking (McLuhan, 1964). In his opinion, "the medium is the message", i.e. the mere fact of watching TV, along with the information perceived there from, produces a significant influence on us. One and the same message published in newspapers and broadcasted by TV will have different effects that will show themselves at different levels of our consciousness. Newsmakers can their transmit their worldview to viewers (Matveeva, Anikeeva, \& Mochalova, 2000). The research by A. Bandura showed that a person can adopt new forms of behavior from movie or news characters (Bandura, 2000). Thus, mass media can affect behavior, emotions, and consciousness of the audience.

A. Danilova analyses in her book "Verbal manipulations in massmedia" different techniques of language influence used by mass-media (Danilova, 2009). One of them we are going to focus on is the technique affecting concepts of danger that is widely employed in news programs. The core of this technique involves resorting to extra-abstract frightening concepts such as crisis, terrorism, flu, etc. Every year or two a new monster is being designed in the last decade to defend against it. The role of the monster is played by terrorists, drug-pushers, Arabs, etc.; and one has to constantly feed one fear after another to urge people to do things they do not want to do, for instance, to approve enormous military expenses (Chomsky, 1972). Consequently, news impacts the audience at a behavioral level as well, in addition to the cognitive and emotional levels. It means those in charge of news programs should responsibly treat the information transmitted.

A. Danilova points out that the number of mentions about terrorism was 63 times higher in 2001 than during previous years, although the death toll of terrorist attacks in 2001 was 4655, against 6454 in 1995 and 6694 in 1998. Therefore, we can conclude that the increased number of news items on terrorism was not induced by more frequent terrorist attacks, but by certain motives of authors of publications and owners of TV channels. The fear technology is that an abstract concept accompanied by such terms as "each", "any", "whole" etc., starts to be used in a vast number of publications and programs. For example: "A terrorist can attack at any time, at any place, and with any weapons" (Washington 
Post). The word gets embedded in day-to-day life, entwined in a personal worldview thus creating a feeling of vulnerability and helplessness (Danilova, 2009).

Naturally, perception of news depends not only on a TV channel policy, views of a team producing programs, but also on specific features of a recipient, its personal experience and psychological characteristics. Consequences of informational influence on mass audience were revealed in papers of different researchers.

For example, Yu.L. Berdnikova describes in her article "Ripples on the Water, or 'Unknown Victims"' a clinical case when post-traumatic distress symptoms were found in different members of the same family after continuous watching of TV programs about acts of terrorism in Moscow. The symptoms exhibited in the son included obsessive military games, his mother suffered from panic attacks, nightmares, and attempts to escape the house at night in an affected state; and the father complained about insomnia and aggressiveness. The woman had been overanxious before, since she had gone through 2 psycho-traumatic situations: staying in a stopped lift and a fire in her country house. Frequent watching of TV programs that highlighted tragic nature of the past events and induced negative perception of reality resulted in "breakdown of her mental defense mechanisms". This family had to go through a long course of psychotherapy to get rid of all their symptoms (Berdnikova, 2004).

S.N. Enikolopov, S.V. Lebedev and E.A. Bobosov (2004) conducted a study of a post-traumatic distress (PTD) based on a pattern of a stressful event reflected by mass-media: hostage-taking during the Nord-Ost musical at the Dubrovka theatre centre. $20 \%$ of those who watched the broadcasts every day were found out to manifest PTD symptoms. This observation gives evidence that significant TV-induced changes may occur in individual consciousness (Enikolopov, Lebedev, \& Bobosov, 2004).

S.N. Enikholopov and A.A. Mkrtychyan analyzed connections among mass-media, terrorism and its consequences. They established that information spread by mass-media after an act of terrorism can cause a chain reaction of panic and fear of death (Enikolopov \& Mkrtchyan, 2010). Also, similar studies were carried out by D. Philips in America and by professors Berger and Lakhod in Israel. Administrations of many countries are deeply concerned with the fact that stress symptoms tend 
to intensify in population, and people more often consult doctors in connection with reactions to the threat of terrorist attack after every largescale tragic event finding coverage in mass-media, for example, after an act of terrorism. A draft project of measures to psychologically protect population from consequences of terrorist attacks known as the USA PATRIOT ACT was brought in the US Congress.

Attention is being paid to this issue in Russia, too: the RF State Duma proposes amendments to the Law "On Mass-Media”, for instance a ban to televise bodies of those died of a terrorist attack. Once massmedia are the new powerful factor affecting the formation of a personal worldview, they require a special psychological research. To assess effects of informational influence, there is a call for both a semantic analysis thereof and for consideration of personality characteristics of a recipient. New methods and techniques are requisite to study impact of mass-media.

The news-related effect of transformation of a danger concept was selected as a working model in the present study. A concept of danger $(C D)$ is an extremely important constituent of a human worldview that considerably affects the quality of life. Perception of the world, an anxiety level depends on a sensation of potential danger. This is why a research in this field is really urgent.

On the one hand, the concept of danger describes objects and events of the real world that pose a threat to an individual, and, on the other hand, a psychological reality created by a subject. Some psychologists distinguish between cognitive and emotional components of the CD which are formed during adaptation to the external world (Sultanov, 2009; Schneier, 2008). Several papers are concerned with three components: a cognitive component, a mental state, and a stable personality distinction (Savchenko \& Golovina, 2006).

The CD cognitive component rests upon the situation assessment according to certain parameters. The weightiest parameters are pinpointed in several papers devoted to potential danger and influence of mass-media. As stated in the paper by T.V. Kornilova: "Improvement of the manner how mass-media inform people about a risk is viewed as the shift of the emphasis from probabilities, on which a lot of attention is normally focused, to hypothetical consequences thereof" (Kornilova, 2003, p. 183). In our study, we aimed to specify a structure of danger concepts represented as individual parameters. 


\section{Objective and tasks of the study}

The objective of this study was to reveal transformational influence of news reports on respondents' CD. We primarily concentrated on the CD cognitive component, because it is the cognitive psychological functions that process information, assess its individual parameters, select the most significant elements, preserve the latter, and use in the form of general concepts. Cognitive processing of information about danger shows itself through changes in parameters of danger assessment.

The study was based on the following scheme: 1) Finding out how danger is conceptualized in consciousness of respondents; 2) Making a list of situations that are usually regarded as dangerous; 3) Determining main parameters of assessing dangerous situations; 4) Analyzing CD transformation induced by short-term and long-term viewing of news content.

\section{Development of Questionnaire Items}

A list of dangerous situations included in the questionnaire was prepared during the preliminary collection of information. First, the respondents answered the question: "What is 'danger'?" The analysis of their responses demonstrated that danger is most often described as certain situations or circumstances that pose a threat to life or health, or hinder satisfying personal demands. Thereafter, the respondents were asked to list certain situations they consider to be dangerous. The set of the most frequently mentioned situations was accepted as a basic (stimulus) material that the respondents had to score (on a 10-point scale) depending on an amount of danger. The responses obtained constituted a list of situations for the "Assessment of Dangerous Situations" Questionnaire. The situations were selected with account of the existing classifications of dangers to include various types of dangers.

The concept of danger can be related to various events and situations, and hence several approaches were employed in the previously developed classifications.

One of such classifications divides dangers according to their origin. Dangers can come from people, from powerful technical systems, biologically or chemically active elements of the environment, sources of information, etc. For instance, military, technological, social, ecologi- 
cal, economic hazards can be distinguished. Danger from radiation and chemical hazards are often mentioned, too (Belkov \& Miroshnichenko, 2008). Dangers can be of an external and an internal (existential) nature (Leont'ev, 2003; Frankl, 1990)

4 main levels of danger manifestations can be singled out: a world (global) level, a level of separate countries, a level of social groups (with different number of members), and an individual level. This approach serves as a foundation for a relevant classification (Korotets, 2003). The classification offered by German psychologist D. Galtung appears to be the most felicitous. He classified dangerous situations into three types using the criterion of satisfaction needs. The scholar highlighted dangers that prevent from satisfying physical, social, and existential needs. For example, the danger of famine or diseases relates to the first type, the dangers of loosing a social status or freedom are included in the second group. The third group is composed of dangers that prevent an individual from satisfying the need for identity, and thus correspond to existential dangers. A similar classification is proposed by Yu. Sherbatykh (2002). Various kinds of fears were divided into three groups in said study, as well: biological, social, and existential fears. The first group includes the fears directly connected with life and health hazards, the second group comprises fears and apprehensions for losing a social status, and the third group of fears is linked to the inner nature of a human being and is typical of all people, any specific situations notwithstanding.

The data received from the poll on a nature of dangers permitted us to elaborate the classification proposed by Yu. Sherbatykh. The reinvented classification represents four major groups of dangers: physical, social, existential, and infernal, or mystic ones, existing in human imagination.

Resting upon the analysis of the existing classifications and the data obtained during the poll on a nature of dangers, we relied on the classification by Yu. Sherbatykh (2002), along with the elaborated classification of dangers (fig.1), which accounts for the CDs represented in the respondents in the most widespread manner. This classification is based on the sources producing dangerous situations. In addition, this classification allows assessing contents of messages transmitted by news programs. Basically, these programs are concerned with physical and social dangers. 
In general, 36 different situations were included in the Questionnaire. Respondents were supposed to measure them according to intensity of dangers. 4 columns were intentionally left blank for situations that the respondents might have wanted to write down themselves.

\section{Development of the scale system of the Questionnaire}

The scales of the Questionnaire are based on parameters of dangerous situations assessment. Two methods were applied to find them: a half-structured interview on "A Concept of Danger", and a modified method of "repertoire grates" by Kelly, intended for assessment of dangerous situations covered by mass-media. 12 respondents (including 6 viewers and 6 authors of news programs) aged 25 to 45 took part in these procedures.

First, the respondents were interviewed on "Dangers in real life and on the screen", and then they were demonstrated pre-recorded news items (video clips) united in 5 groups consisting of 3 stories each. The video clips were selected such so as to represent different types of dangers in the most complete manner possible. Having watched the video materials, the respondents made written accounts similar to those prepared according to the Kelly method.

As a result, 5 parameters of assessing dangerous situations were distinguished: intensity, global character, probability, controllability, proximity. The intensity parameter measures potential damage caused by a dangerous situation: the parameter of a global character assesses how deep an individual may be affected by a situation, whether it relates to the individual him/herself, his/her family, or the country in general; the probability parameter aims to determine how likely such a situation may occur in someone's life; the controllability parameter measures how an individual him/herself can affect a situation, if the latter occurs; the proximity parameter assesses a personal experience of involvement into such a situation and depends whether a respondent or his/her relatives and friends have ever faced this situation.

The data were analyzed on the basis of frequency content analysis. We compared the number of mentioned word markers relating to parameter categories.

The comparison of frequency of the 5 parameters revealed significant distinctions neither in concepts of danger, nor in opinions as to a 
role of TV communication in the formation of dangers in authors and in viewers. It may be fairly concluded that professional affiliation cannot be regarded as a key factor in the $\mathrm{CD}$ development.

The frequency content-analysis showed that controllability appears to be the most crucial among these 5 parameters. If an individual believes that he/she can foresee a situation, have some influence upon it or even overcome it successfully, it is viewed as far less dangerous.

These parameters built a foundation for scales of our Questionnaire. The Questionnaire was further used in our major study consisting of two steps. In the first step, the Questionnaire contained 36 situations and one scale (integral assessment of how dangerous situations are). Then the Questionnaire was amended after the first step. In the second step, 12 situations and the five main parameters of intensity, global character, probability, controllability, and danger proximity were added.

\section{CD transformations affected by long-term viewing of news content}

The first step involving 53 respondents ( 20 women, 23 men) aimed to reveal how long-term viewing (during three weeks) of news content affected a concept of danger.

Procedure. The respondents filled in the "Assessment of Dangerous Situations" Questionnaire. They were watching 10 p.m. news programs of the NTV channel (Moscow) within three weeks, and they answered the same questions again in the end of each week.

Results. Separate ratings for each dangerous situation were calculated on the basis of average scores put by the respondents according to criteria of perceivable subjective danger prior to and subsequent to viewing the news programs.

Prior to viewing of the video clips, the following situations got the highest scores: war, grievous loss of a close relative or a friend, dangerous disease, fear of becoming a hostage. All these situations are explicitly connected with the universal fear of death in this or that way. Women tend to attach slightly more importance to loss of a close relative or a friend, and to a dangerous disease than men. It may be connected with their more intense family orientation and health care in comparison with men. The category of the least dangerous situations consisted of: watching news programs, unexpected blackouts, or seeing a comet in the sky. 
After watching news programs the scores in the danger scale increased considerably for 17 situations of 36 (verified statistical discrepancies at the level of 0.05 were obtained), with the statistics having been processed according to the Friedman's criterion. Sometimes a direct connection between these transformations and specific messages could be traced: for example, a girl was reported to have been missing in Krasnoyarsk, and the participants showed more concern about their relatives thereafter. We believe that the increase in scores in the majority of the situations is mainly connected not with certain messages, but rather with the fact that news induces a more watchful attitude to the world, in which events are often indefinite and unpredictable.

New situations perceived as dangerous appeared, as well. A fire was mentioned most constantly and persistently. During the second week of viewing, $40 \%$ of the respondents began to fill fire in the form of dangerous situations. Obviously, it was connected with the news on a fire in a retirement home that had involved a number of victims.

Therefore, we registered all the possible transformations of the CD described by A.A. Leont'ev (1975), namely: emergence of new objects, changes in personal attitude to dangers, and formation of a general anxious mood.

The task of the second step of the study was to find out how the short-term viewing of news content affects CD and how parameters for assessment of dangerous situations transform. The original Questionnaire was modified to complete this task: instead of one "Danger" integral scale the respondents were asked to assess each situation with 5 parameters: intenseness, probability, control possibility, global character, proximity.

Procedure. The respondents were demonstrated a 45 -minute record of news programs reflecting different kinds of hazards: for example, earthquakes, hostage-taking, car crashes, etc. The experimental group included 60 men and 60 women, the control group consisted of 20 men and 20 women. The age of the respondents was 18 to 25 . The study schedule was meant to analyze the CD before and after viewing the news. News stories were selected so as to represent different types of hazards.

Results. The results of this experiment demonstrated that even short-term viewing of news messages had a significant influence upon the concepts of danger and involved the change in a ratio of the selected parameters as well. The results were verified by means of statistic pro- 
cessing of the data. The effect of influence was somewhat different in male and female groups.

Prior to watching the news, men manifested higher subjective intensity of danger than after watching. The Vilkonson's criterion was used for statistical processing of dependent samples. There was also a significant increase (as high as 0.05) in subjective assessment of probability of situations, and as well of their subjective proximity to individuals. The parameter of subjective uncontrollability of a dangerous event rose after viewing the news, while the subjective globality slightly went down.

The news upon the women in another manner, though. Unlike the men, they showed lower indices of subjective uncontrollability of a dangerous event, but higher indices of a global character and intensity of dangers. Female scores according to parameters of subjective assessment of probability of situations and their subjective proximity turned out to be higher, like in men.

We believe that these differently directed trends exhibited both by men and women could be explained by their different life strategies, together with psychological differences between the genders. News programs make men think about global processes, believe that every event can impact lives of many people; under the influence of news programs, women would rather concentrate on events that are likely to occur in their own life and in their families.

Another outcome of our study was a new classification of dangers. Unlike the previously suggested classification, the present CD classification does not rest on sources of danger, but on internal processes of assessing situations, which becomes evident with the changes in the CD parameters. This classification takes into account subjectivity in an attitude towards a danger. Moreover, the classification helps to investigate which parameters should be evaluated to trace distortion of a general integrative assessment of danger intensity, said distortion being possible under the influence of information fed by mass-media.

The cluster analysis in the SPSS program revealed that concepts of dangerous situations may be divided into 4 main types.

1) The first type includes high intensity dangers that can hardly be affected. It is an extremely difficult to overcome them. An individual is lonely in the face of these dangers that can be called "invincible" or "inevitable". These dangers encompass: becoming old, changes in gov- 
ernment agencies, unexpected death, death of relatives and close fiends, beginning of a thunderstorm.

2) The second type includes the majority of the dangers set forth in our Questionnaire. These dangers may be called "familiar". Of course, such events do not occur every day, yet many individuals have already faced such dangers and acquired certain experience in dealing with them. These dangers include: relatives' returning home late, unexpected blackouts, a quarrel, embarrassing situations in public, walking along a dark street, etc.

3) The third type consists of such dangers as pauperization; feel of desolation; dismissal; touching spiders, snakes; swimming far out in the sea; revenge for one's sins, etc. Basically, this type includes dangerous situations in which people become involved due to their own carelessness, lack of activity, short-sightedness, and bear certain responsibility for what has happened. Inability to deal with such situations may be called retribution for carelessness or incompetence. The realization that such circumstances are possible makes people be more active and aware.

4) The fourth type of dangers lists: beginning of war, earthquake, plane or train crash, floods, tsunami, fire, etc. These dangers are characterized with a high level of destructiveness, and they can hardly be surmounted. These are catastrophic situations that occur not so often and that can hardly be influenced. High globality is a characteristic feature of such dangers, as other people may suffer there from.

The CD structure changes considerably after viewing news stories. The "familiar dangers" of the second type now start to be considered as less controllable. Catastrophic situations become subjectively more proximate, yet their subjective controllability rises simultaneously, and the subjective intensiveness remains unaltered. Special emphasis should be given to the observation that it is the fourth (catastrophic) type which seems subjectively the most proximate after watching news, with the other types having been pushed to the background. The above-stated allows us to conclude that news programs can distract people from their everyday problems. Highly likely, it is due to the psychological effect of "belonging to the whole world" that news enjoys popularity. When an individual feels this involvement, his/her own problems appear to seem less complicated and unsolvable. M. McLuhan gives a similar explanation of this fact (McLuhan, 1964). 
We have to highlight in conclusion that news programs should be subjected to special adjustment in order to provide information safety and prevent their negative impact. News programs should be compiled such that they would contain information about events, along with both positive and negative emotions; at the same time they should be targeted at the increase in the controllability feeling, and teach how to overcome a dangerous situation.

\section{References}

Bandura, A. (2000). Teorija socialnogo nauchenija [Social Learning Theory]. St. Petersburg: Evrazija.

Bel'kov, O.A., \& Miroshnichenko, V.M. (2008). Opasnost' kak social'noe yavlenie i nauchnoe ponyatie [Danger as social phenomenon and scientific notion]. Problemi bezopasnosti. Bjulleten' nauchno-issledovatel'skogo centra "Nauka-XXI" [Security issues. Bulletin of scientific research center "Nauka-XXI"], 1, 18-64.

Berdnikova, Yu.L. (2004). Krugi na vode, ili "neizvestny’e postradavshie" [Ripples on the Water, or "Unknown Victims"]. In M.M. Reshetnikov (Ed.), Psihologiya i psihopatologiya terrorizma. Gumanitarny'e strategii antiterrora [Psychology and psychopathology of terrorism. Human anti-terror strategy] (pp. 169-176). St. Petersburg: Vostochno-Evropejskij Institut Psihoanaliza.

Chomsky, N.A. (1972). Jazyk i myshlenie [Language and Mind]. Moscow: Moscow State University.

Danilova, A.A. (2009). Manipulirovanie slovom $v$ sredstvah massovoj informacii [Manipulation of the word in the media]. Moscow: Dobrosvet, "KDU".

Enikolopov, S.N, Lebedev, S.V., \& Bobosov, E.A. (2004). Vliyanie ekstremalnogo soby'tiya na kosvenny'h uchastnikov [The influence of extreme events on the indirect participants] // Psihologicheskij zhurnal [Psychological Journal], 25 (6), 73-76.

Enikolopov, S.N., \& Mkrtchyan A.A. (2010). Psihologicheskie posledstviya terrorizma i rol' SMI v protsesse ih formirovaniya [The psychological consequences of terrorism and the role of media in the process of their formation]. Nacionalny'j psihologicheskij zhurnal [National Psychological Journal], 2(4), 41-46.

Frankl, V. (1990). Chelovek v poiskah smysla [Man's Search for Meaning]. Moscow: Progress.

Kornilova, T.V. (2003). Psihologiya riska i prinyatiya reshenij [Psychology of risk and decision-making]. Moscow: Aspekt Press.

Korotets, V.I. (2003). Opasnost' i bezopasnost' v sovremennom mire: filosofskokul'turologicheskij analiz [The danger and safety in the modern world: the philosophical and culturological analysis]: Dis. kand. filos. nauk. Rostov-na-Donu. 
Leontev, A.A. (1975). Obshhenie kak ob'ekt psihologicheskogo issledovaniya [Общение как объект психологического исследования]. In E.V. Shorohova (Ed.), Metodologicheskie problemy socialnoj psihologii [Methodological problems of social psychology] (pp. 106-123). Moscow: Nauka.

Leontev, D.A. (2003). Ekzistencialnaya trevoga i kak s nej borot'sya [Existencial anxiety and how to fight with it]. Moskovskij psihoterapevticheskij zhurnal [Moscow Psychotherapeutic Journal], 2, 107-119.

McLuhan, M. (1964). Understanding Media: The Extensions of Man. New York: McGraw Hill.

Matveeva, L.V., Anikeeva, T.Ya, \& Mochalova, Yu.V. (2000). Psihologiya televizionnoj kommunikatsii [Psychology of television communication]. Moscow: UMK "Psihologija".

Savchenko, T.N., \& Golovina, G.M. (2006). Subektivnoe kachestvo zhizni:podxody', metody' otsenki, prikladny'e issledovaniya [Subjective quality of life: approaches, methods, evaluation, applied research]. Moscow: Institut psihologii RAN.

Schneier, B. (2008). The Psychology of security. URL: http://www.schneier.com/ essay-155.html

Sherbatykh, Yu. (2002). Psihologiya straha: Populyarnaya enciklopediya [Psychology of fear: Popular encyclopedia]. Moscow: Jeksmo.

Sultanov, T.N. (2009). Otnoshenie sportsmenov k ekstremal'ny'm situatsiyam [The athletes attitude towards extreme situations]. Uchen. zapiski un-ta im. P.F. Lesgafta [Scientific issues of Lesgaft university], 2, 72-76.

Vygotsky, L.S. (1960). Razvitie vysshih psihicheskih funktsij [The development of higher mental functions]. Moscow: APN. 